\title{
АНАЛИЗ СИСТЕМЫ КАДАСТРОВОГО УЧЕТА МЕСТОРОЖДЕНИЙ В РОССИЙСКОЙ ФЕДЕРАЦИИ
}

\section{Елизавета Олеговна Клименко}

Сибирский государственный университет геосистем и технологий, 630108, Россия, г. Новосибирск, ул. Плахотного, 10, обучающийся, тел. (923)595-36-60, e-mail: elizaveta.klimenko.98@mail.ru

\section{Анатолий Викторович Ериов}

Сибирский государственный университет геосистем и технологий, 630108, Россия, г. Новосибирск, ул. Плахотного, 10, кандидат технических наук, доцент кафедры кадастра и территориального планирования, тел. (961)845-44-09, e-mail: er-tos@inbox.ru

В статье рассмотрены основные понятия, нормативные документы и порядок ведения кадастра месторождений и проявлений полезных ископаемых в Российской Федерации.

Ключевые слова: кадастр месторождений и проявлений полезных ископаемых, минеральные ресурсы, недра, федеральный закон

\section{ANALYSIS OF THE SYSTEM OF CADASTRAL REGISTRATION OF DEPOSITS IN THE RUSSIAN FEDERATION}

\section{Elizaveta O. Klimenko}

Siberian State University of Geosystems and Technologies, 10, Plakhotnogo St., Novosibirsk, 630108, Russia, Student, phone: (923)595-36-60, e-mail: elizaveta.klimenko.98@mail.ru

\section{Anatoly V. Ershov}

Siberian State University of Geosystems and Technologies, 10, Plakhotnogo St., Novosibirsk, 630108, Russia, Ph. D., Associate Professor, Department of Cadastre and Territorial Planning, phone: (961)845-44-09, e-mail: er-tos@inbox.ru

The article discusses the basic concepts, regulatory documents and procedures for maintaining inventory of deposits and occurrences of minerals in the Russian Federation.

Keywords: cadastre of deposits and occurrences of minerals, mineral resources, subsoil, federal law

На сегодняшний день сложившиеся в современном мире условия говорят о необходимости получения стандартизированной и достоверной информации о природных ресурсах. Для полного урегулирования данной задачи необходима эффективная система государственного управления природопользованием и недропользованием.

Целью исследования является выполнение анализа существующей системы кадастра месторождений и проявлений полезных ископаемых в Российской Федерации.

В разных странах ведением кадастра занимаются государственные межведомственные организации. В России составлением и ведением Государственного кадастра месторождений осуществляется Федеральным агентством по недропользованию (Роснедра). 
Государственный кадастр месторождений и проявлений полезных ископаемых (ГКМ РФ) - это систематизированный свод сведений о месторождениях и проявлениях полезных ископаемых, геофизических аномалиях и геологических структурах, перспективных на поиск или рекомендованных для проверки.

Месторождение - это природное скопление полезного ископаемого, которое в количественном и качественном отношениях удовлетворяет требованиям промышленности и может быть предметом разработки.

По мере развития научно-технического прогресса объемы добычи полезных ископаемых и число их видов непрерывно увеличивались. На сегодняшний день в промышленности используются 89 химических элементов, содержащихся в земной коре.

Добыча полезные ископаемые необходима для обеспечения населения сырьем, необходимым для производства продукции, а также строительства зданий, дорог, создания техники, оборудования и т.д.

Виды месторождений:

1. Эндогенные - залежи, связанные с геохимическими процессами глубинных частей Земли.

2. Экзогенные (поверхностные) - залежи, связанные с древними и современными геохимическими процессами на поверхности Земли. Различают остаточные, инфильтрационные, россыпные и осадочные гипергенные месторождения.

3. Метаморфогенные - возникают в глубинных зонах земной коры под воздействием высоких температур и давлений.

Основные цели кадастра месторождений $[1,2]$ :

- обеспечение разработки федеральных и региональных программ геологического изучения недр;

- комплексное использование месторождений полезных ископаемых;

- рациональное размещение предприятий по их добыче;

- другие народно-хозяйственные цели.

Кадастр месторождений должен включать в себя следующую информацию: $[3-5,10]$ :

- сведения по каждому месторождению, характеризующих количество и качество основных и совместно с ними залегающих полезных ископаемых;

- сведения о содержащихся в них компонентах;

- горно-технические, гидрогеологические, экологические и другие условия разработки месторождений;

- геолого-экономическая оценка каждого месторождения, а также сведения по выявленным проявлениям полезных ископаемых;

- месторождения с запасами полезных ископаемых, учтенными Государственным балансом запасов полезных ископаемых;

- месторождения еще не учтенные, на которых завершены оценочные работы или разведка;

- месторождения, которые сняты с учета Государственным балансом запасов полезных ископаемых; 
- выработанные месторождения;

- проявления твердых полезных ископаемых, при наличии минимум одного тела (залежи), по качеству удовлетворяющих основным требованиям промышленности к месторождениям, но количество запасов, которых либо не установлено, либо им не дана промышленная оценка.

ГКМ РФ создан для плодотворного изучения значимых параметров и свойств месторождений и проявлений полезных ископаемых, в нем содержатся отсылки к более подробному описанию - в отчетах о результатах геологоразведочных работ, протоколах по Государственной экспертизе запасов и других исходных документах.

Правовой основой для создания государственного кадастра месторождений и проявлений полезных ископаемых является Закон РФ «О недрах» [9].

В приказе Минприроды России от 14 июля 2009 г. №207 регламентированы процедуры ведения государственного кадастра месторождений и проявлений полезных ископаемых и государственного баланса запасов полезных ископаемых. Данная государственная функция возложена на Роснедра.

Согласно статье 30 Закона Российской Федерации «О недрах» ГКМ РФ проводит специальные программы на региональном и федеральном уровнях, в целях геологического изучения недр, комплексного использования месторождений полезных ископаемых, рационального размещения предприятий по их добыче. В ГКМ РФ заносятся сведения по каждому месторождению, в том числе о количестве и качестве основных и совместно с ними залегающих полезных ископаемых, о содержащихся в них компонентах, а также о горно-технических, гидрогеологических, экологических и других условиях разработки месторождения. Также ГКМ РФ содержит геолого-экономическую оценку каждого месторождения и данные по выявленным проявлениям полезных ископаемых [6-8].

Работы по ведению ГКМ РФ регламентируются рядом нормативных документов, а также ведомственными инструкциями и руководствами.

Основной документ кадастра месторождений и проявлений - это паспорт конкретного месторождения (или проявления) полезного ископаемого.

В паспорте месторождения содержатся:

- основные геологические, технологические и геологоэкономические характеристики месторождения;

- свойства руд и вмещающих пород;

- запасы полезных ископаемых, технологии их извлечения и переработки.

Паспорт ГКМ РФ - единственный документ, который содержит полную информацию описывающий месторождение.

Паспорта объектов учета ГКМ РФ РФ составляются по следующим разделам:

- А - месторождения металлических полезных ископаемых;

- Б - месторождения неметаллических полезных ископаемых;

- В - россыпные месторождения;

- Г - проявления твердых и россыпных полезных ископаемых;

- Д - месторождения и проявления нефти и газа;

- Е - месторождения угля и горючих сланцев;

- Ж - месторождения гидроминерального сырья. 
В результате выполненного исследования можно сделать вывод, что действующая система ГКМ РФ обладает сложной разветвленной структурой и эффективно собирает и систематизирует сведения о запасах и добыче полезных ископаемых в недрах РФ. Собранная информация упорядочивается в виде паспортов, что облегчает эффективный доступ специалистов к ней, объем этой информации достаточен, чтобы получить общее представление об обеспеченности региона минерально-сырьевыми ресурсами.

\section{БИБЛИОГРАФИЧЕСКИЙ СПИСОК}

1. Авдонин, В. В. Геология полезных ископаемых / В.В. Авдонин, В.И. Старостин. - М.: Академия, 2015. - 384 с.

2. Всесоюзная конференция "Научно-технические проблемы комплексного использования месторождений полезных ископаемых". Выпуск 5. - М.: ПИК ВИНИТИ, 2015. - 214 с.

3. Илюшина, Т.В. Кадастр природных ресурсов России / Т.В. Илюшина. - M.: Palmarium Academic Publishing, 2019. - 324 c.

4. Информационно-аналитический цент Минерал [Электронный ресурс]. Режим доступа: URL: http://www.mineral.ru/Library/Docs/114/127/index.html/ - Загл. с экрана.

5. Кадастровый учет месторождений и проявлений полезных ископаемых в Российской Федерации. Проблемы и пути их решения [Электронный ресурс]. Режим доступа: URL: $\quad$ https://cyberleninka.ru/article/n/kadastrovyy-uchet-mestorozhdeniy-i-proyavleniypoleznyh-iskopaemyh-v-rossiyskoy-federatsii-novye-problemy-i-perspektivy/ - Загл. с экрана.

6. Основные направления развития законодательства Российской Федерации в сфере учета информации о состоянии недр [Электронный ресурс]. Режим доступа: URL: https://cyberleninka.ru/article/n/osnovnye-napravleniya-razvitiya-zakonodatelstva-rossiyskoyfederatsii-v-sfere-ucheta-informatsii-o-sostoyanii-nedr/ - Загл. с экрана.

7. Российская Федерация. Приказ: Об утверждении положения о порядке учета запасов полезных ископаемых, постановки их на баланс и списания с баланса запасов [текст]: приказ Минэкономразвития РФ от 09.07.97 N 122 // СПС «Консультант Плюс».

8. Российская Федерация. Приказ: Об утверждении Порядка рассмотрения заявок на получение права пользования недрами для геологического изучения недр (за исключением недр на участках недр федерального значения и участках недр местного значения) [Текст]: от 10.10.16 N 583// СПС «Консультант Плюс».

9. Российская Федерация. Законы: О недрах [текст]: федер. закон от 21.02.92 N 2395-I (ред. от 30.11.2011) // СПС Консультант Плюс.

10. Современное состояние и перспективы развития ведомственных кадастров природных ресурсов [Электронный ресурс]. Режим доступа: URL: https://cyberleninka.ru/article/n/sovremennoe-sostoyanie-i-perspektivy-razvitiya-vedomstvennyhkadastrov-prirodnyh-resursov/ - Загл. с экрана. 